\title{
Definition of oil change intervals based on the analysis of selected physicochemical properties of used engine oils
}

The paper presents the results of a thorough analysis of selected physicochemical parameters of engine oils at the end of their useful life, based on the oil change intervals assumed by vehicle users. Twelve samples of used Castrol Edge 5W/30 synthetic oil and five samples of used Castrol Magnatec 10W/40 semi-synthetic oil were tested. The Eralytics's ERASPEC OIL device was used for the assessment of the following parameters: degree of oxidation, degree of nitration, degree of sulfonation, water content, glycol content, total base number (TBN), total acid number (TAN) and kinematic viscosity at $40^{\circ} \mathrm{C}$ and $100^{\circ} \mathrm{C}$. The research was conducted on the basis of the ASTM E2412-10 standard. The results regarding the parameter limit exceedances have also been presented in the paper. For both synthetic and semi-synthetic oils, the exceedance of kinematic viscosity measured at $40^{\circ} \mathrm{C}$ was particularly striking. In fourteen samples (out of seventeen tested), at least one exceedance of the limit value (out of nine analyzed) has been observed.

Key words: degradation, engine oil, oil change, Eraspec, FT-IR, in-service oil

\section{Introduction}

Lubricating oil plays an important role in ensuring engine performance and durability. However, extreme operating conditions of a combustion engine such as high temperature, high pressure and cold engine startup, strongly affect the acceleration of oil degradation. Thus, for any given inservice oil, both the changes in the chemical properties and the accompanying, broadly understood, multi-faceted deterioration of quality may be equally observed [10].

A precise determination of the degree of oil degradation is very important for technical and economic reasons; however, due to oftentimes severe and varying operating conditions, the oil aging processes should be considered individually for each drive unit $[2,12]$. Most of the changes in the parameters of in-service oils during actual operation are difficult to detect. It is equally difficult to recognize (during oil operation) the moment when the oil reaches critical levels of its physicochemical properties. It may often be observed that after some period of apparently proper operation of the engine, a sudden increase in its wear or the engine failure occurs. In such cases, an in-depth analysis of the potential causes of the failure is rarely conducted, although it might reveal the impact of oil quality on the incident. Frequent oil contamination checks may help prevent engine failure as oil is a valuable source of information about the processes and causes of engine wear [8]. The effects of improper oil use or incorrectly set oil change intervals are apparent when the engine is being repaired. On the basis of the inspection of the removed pistons, the formation and the type of impurities deposited on them can be determined. It is extremely important to regularly replace used engine oil with the fresh one, which will clean the whole lubrication system (at the initial phase of service life) and then secure it at subsequent stages of use [3]. Information on the condition of an in-service lubricating oil is usually obtained through the means of analyzing changes in selected parameters in relation to the fresh products or comparing those parameters with their limit values [13]. The degree of engine oil degradation can be accurately determined by laboratory methods through analyzing a series of oil samples. With the used of laboratory methods, a number of oil parameters such as: kinematic viscosity, viscosity index, degree of oxidation, nitration and sulfonation, total acid and total base number, water and glycol content, or antioxidant content can be determined. This gives a full picture of the oil condition. Due to the fact that engine oils undergo a process of degradation under all operating conditions, they must be periodically changed. The generally accepted criteria for replacing engine oil in passenger cars i.e.: the number of kilometers traveled or the schedules based on average data prepared for different vehicles, are not always sufficient to accurately assess the level of oil deterioration [5, 9]. Too short oil change interval results in increased vehicle maintenance costs. On the other hand, when the oil change interval is too long, the engine wear may increase sharply, which might even lead to engine damage $[1,4]$. Thus, the decision regarding oil change interval should mainly depend on the use and operating conditions of the vehicle [4]. The purpose of the study was to assess whether the criteria generally applied by the vehicle users as regards oil change interval are appropriate. The paper presents the results of a thorough analysis of selected physicochemical parameters of engine oils at the end of their useful life, based on the oil change intervals assumed by vehicle users. All engine oils tested came from cars used by private individuals. The parameters selected for testing provide insight into the processes of oil aging under operating conditions and contribute to determining the remaining useful life of oils $[6,7]$.

\section{Materials and methods}

The research material comprised of a series of engine oil samples collected during a standard oil change procedure from passenger cars of different manufacturers and with various levels of mileage. Only the samples of synthetic oils Castrol Edge 5W/30 and Castrol Magnatec 10W/40 were considered in the test. All of the oil samples were obtained from two car repair and servicing workshops in the area of Lublin Voivodeship. Twelve samples of used Castrol Edge 5W/30 synthetic oil and five samples of used 
Castrol Magnatec 10W/40 semi-synthetic oil were tested. More detailed information concerning the cars used in the tests are presented in Table 1 . The sample code includes the name of the test oil (CE - Castrol Edge, CM - Castrol Magnatec) and the type of engine [D-diesel, G-Gasoline].

Table 1. Detailed information concerning the cars used in the test

\begin{tabular}{|c|c|c|c|c|c|c|}
\hline & & Make of car & Engine & $\begin{array}{l}\text { Sample } \\
\text { code }\end{array}$ & Car mileage & $\begin{array}{c}\text { Mileage } \\
\text { since last } \\
\text { oil change }\end{array}$ \\
\hline \multirow{12}{*}{ 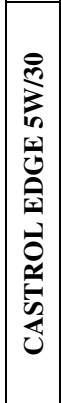 } & 1. & Volvo XC 60 & diesel & CED01 & $52000 \mathrm{~km}$ & $10000 \mathrm{~km}$ \\
\hline & 2. & Volvo V50 & diesel & CED02 & $192000 \mathrm{~km}$ & $10000 \mathrm{~km}$ \\
\hline & 3. & Nissan $X$ trial & diesel & CED03 & $243000 \mathrm{~km}$ & $11000 \mathrm{~km}$ \\
\hline & 4. & Opel Astra & diesel & CED04 & $205000 \mathrm{~km}$ & $12000 \mathrm{~km}$ \\
\hline & 5. & Audi A6 & gasoline & CEG05 & $240000 \mathrm{~km}$ & $12000 \mathrm{~km}$ \\
\hline & 6. & Seat Leon & diesel & CED06 & $122000 \mathrm{~km}$ & $14000 \mathrm{~km}$ \\
\hline & 7. & Audi Q7 & diesel & CED07 & $166000 \mathrm{~km}$ & $15000 \mathrm{~km}$ \\
\hline & 8. & Skoda Fabia & diesel & CED08 & $136000 \mathrm{~km}$ & $15000 \mathrm{~km}$ \\
\hline & 9. & Skoda Fabia & diesel & CED09 & $120000 \mathrm{~km}$ & $16000 \mathrm{~km}$ \\
\hline & 10. & VW Touareg & diesel & CED10 & $293000 \mathrm{~km}$ & $24000 \mathrm{~km}$ \\
\hline & 11. & BMW X5 & diesel & CED11 & $212000 \mathrm{~km}$ & $28000 \mathrm{~km}$ \\
\hline & 12. & BMW E61 & diesel & CED12 & $169000 \mathrm{~km}$ & $30000 \mathrm{~km}$ \\
\hline \multirow{5}{*}{ 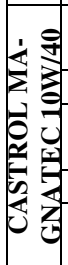 } & 1. & $\begin{array}{c}\text { Ford Mondeo } \\
\text { MK II }\end{array}$ & diesel & CMD01 & $294000 \mathrm{~km}$ & $10000 \mathrm{~km}$ \\
\hline & 2. & Mercedes C220 & diesel & CMD02 & $195000 \mathrm{~km}$ & $10000 \mathrm{~km}$ \\
\hline & 3. & $\begin{array}{c}\text { Ford Mondeo } \\
\text { MK II }\end{array}$ & gasoline & CMG03 & $233000 \mathrm{~km}$ & $12000 \mathrm{~km}$ \\
\hline & 4. & Daihatsu Terios & gasoline & CMG04 & $181000 \mathrm{~km}$ & $13000 \mathrm{~km}$ \\
\hline & & Skoda Romster & $\begin{array}{l}\text { gasoline } \\
+ \text { LPG }\end{array}$ & CMG05 & $280000 \mathrm{~km}$ & $15000 \mathrm{~km}$ \\
\hline
\end{tabular}

In order to determine the qualitative changes of the engine oils at the end of their useful life, they were analyzed with the use of ERASPEC OIL apparatus manufactured by
Eralytics. It is a portable mid-range infrared FT-IR spectrometer designed to measure the key parameters of lubricating oils, which fully complies with the requirements of European and American standards. The device was used for the assessment of the following parameters: degree of oxidation, degree of nitration, degree of sulfonation, water content, glycol content, total base number (TBN), total acid number (TAN) and kinematic viscosity at $40^{\circ} \mathrm{C}$ and $100^{\circ} \mathrm{C}$. The tests were conducted on the basis of the ASTM E2412-10 standard. The samples and the apparatus were prepared in accordance with the manufacturer's recommendations printed in the user manual. In order to determine the condition of oils, the limit values for the parameters tested were adopted based on the subject literature. This also required determination of the initial values of the selected oils; that is why, the samples of fresh Castrol Edge and Magnatec oils were tested. The physicochemical properties of the oils, measured at the beginning of the experiment are presented in Table 2. Details of the adopted limit levels and values that may be found in the subject literature are given in Table 3 .

Table 2. The physicochemical properties (as measured) of fresh Castrol Edge 5W/30 and Castrol Magnatec 10W/40 engine oils used in the tests

\begin{tabular}{|l|c|c|c|}
\hline Name & Unit & $\begin{array}{c}\text { Castrol Edge } \\
5 \mathrm{~W} / 30\end{array}$ & $\begin{array}{c}\text { Castrol Mag- } \\
\text { natec 10W/40 }\end{array}$ \\
\hline $\begin{array}{l}\text { Kinematic viscosity } \\
\text { at } 40^{\circ} \mathrm{C}\end{array}$ & $\mathrm{mm}^{2} / \mathrm{s}$ & 68,7 & 68,2 \\
\hline $\begin{array}{l}\text { Kinematic viscosity } \\
\text { at } 100^{\circ} \mathrm{C}\end{array}$ & $\mathrm{mm}^{2} / \mathrm{s}$ & 11,0 & 10,9 \\
\hline TBN & $\mathrm{mgKOH} / \mathrm{g}$ & 5,52 & 7,38 \\
\hline TAN & $\mathrm{mgKOH} / \mathrm{g}$ & 2,16 & 1,38 \\
\hline
\end{tabular}

Table 3. Details related to limit values

\begin{tabular}{|c|c|c|c|c|c|c|}
\hline \multirow{3}{*}{ Parameter } & \multirow{3}{*}{ Unit } & \multicolumn{5}{|c|}{ Limit values } \\
\hline & & \multicolumn{4}{|c|}{ According to subject literature } & \multirow{2}{*}{ Adopted in this paper } \\
\hline & & [11] & [5] & SAE J300-2015 & [10] & \\
\hline $\begin{array}{l}\text { Kinematic viscosity } \\
\left(100^{\circ} \mathrm{C}\right)\end{array}$ & {$\left[\mathrm{mm}^{2} / \mathrm{s}\right]$} & $14.5-15.7$ & - & $\begin{array}{c}(5 \mathrm{~W})-\min 9.3 \\
\max <12,5 \\
(10 \mathrm{~W})-\min 12,5 \\
\max <16,3\end{array}$ & $\pm 15 \%$ & $\begin{array}{c} \pm 15 \%=> \\
(5 \mathrm{~W})-\min 9.3 ; \max 12.5 \\
(10 \mathrm{~W})-\min 9.4 ; \max 12.7\end{array}$ \\
\hline Total Acid Number & {$[\mathrm{mg} \mathrm{KOH} / \mathrm{g}]$} & $\begin{array}{l}\text { At the point of inter- } \\
\text { section, of both TAN } \\
\& \text { TBN trend lines, }\end{array}$ & - & - & $\begin{array}{c}6 \mathrm{mg} \\
\mathrm{KOH} / \mathrm{g}\end{array}$ & $\begin{array}{c}+2.5 \mathrm{mg} \mathrm{KOH} / \mathrm{g} \\
(5 \mathrm{~W})-\max 3.9 \\
(10 \mathrm{~W})-\max 4.7 \\
\end{array}$ \\
\hline Total Base Number & {$[\mathrm{mg} \mathrm{KOH} / \mathrm{g}]$} & $50 \%$ reduction & $<30 \%$ & - & $<30 \%$ & $\begin{array}{c}<50 \% \\
(5 \mathrm{~W})-\max 3.7 \\
(10 \mathrm{~W})-\max 2.8\end{array}$ \\
\hline Degree of oxidation & {$[\mathrm{Abs} /(0.1 \mathrm{~mm})]$} & - & $>1.0$ & - & $>0.4$ & $>0.4$ \\
\hline Degree of sulfonation & {$[\mathrm{Abs} /(0.1 \mathrm{~mm})]$} & - & $>1.0$ & - & $>0.4$ & $>0.4$ \\
\hline Water content & {$[\% \mathrm{~m} / \mathrm{m}]$} & - & $>0.3$ & - & - & $>0.2$ \\
\hline Glycol content & {$[\% \mathrm{~m} / \mathrm{m}]$} & - & $>0.3$ & - & - & $>0.3$ \\
\hline
\end{tabular}

Source: own elaboration

The measurements were made in triplicate. The results obtained were statistically analyzed using the Statistica 12 software package. In order to present the obtained results, a box and whisker chart was used for each of the analyzed variables, in three kilometer intervals (10-12k, 14-16k and 24-30k). The following items were included in the charts: values tested (outliers and extremes); median and data frame (quartiles -25 . and 75 . percentile).

\section{Results and discussion}

All of the Castrol Magnatec 10W40 semi-synthetic oil samples tested exceeded the kinematic viscosity limit value at $40^{\circ} \mathrm{C}$ (Fig. 1). For the CMG03 sample, the oil viscosity exceeded the minimum limit of critical value, whereas in the rest of the samples, even the maximum value adopted was exceeded. It should be noted that higher viscosity was 
observed in the group of vehicles with higher mileage $(14,000-16,000 \mathrm{~km})$.

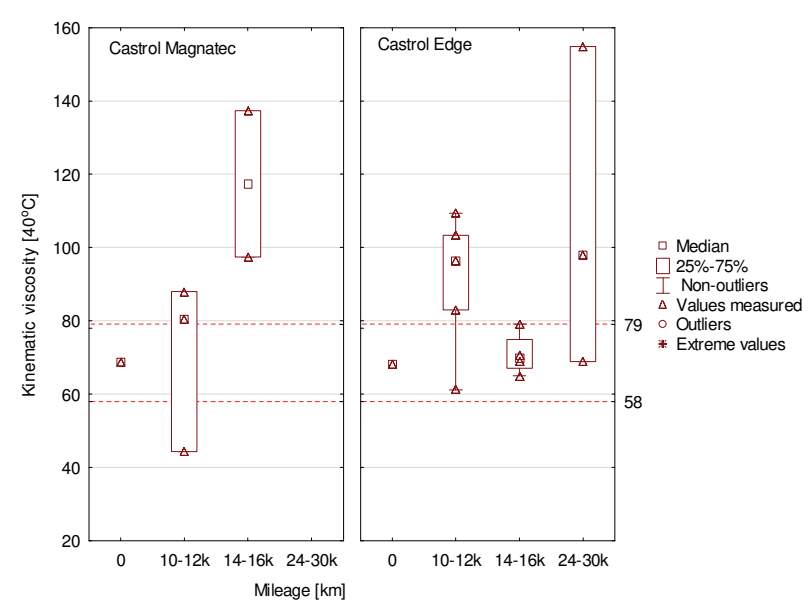

Fig. 1. Kinematic viscosity at $40^{\circ} \mathrm{C}$ of the engine oils tested

Upon analyzing the results of kinematic viscosity tests at $40^{\circ} \mathrm{C}$ for Castrol Edge 5W30 synthetic oil (Fig. 1) it was found that five of the samples tested were within the acceptable range. For seven of the samples tested, the upper limit was exceeded, indicating that the viscosity of the oil became too high.

Similarly, analyzing the kinematic viscosity at $100^{\circ} \mathrm{C}$ of used engine oils (Fig. 2), it can be observed that in three of the samples of semi-synthetic Castrol Magnatec 10W40 oil, the critical values were obtained. These were the following oil samples: CMG04, CMD02 and CMG03. For the first two samples, too high oil viscosity $\left(14.27\right.$ and $12.8 \mathrm{~mm}^{2} / \mathrm{s}$, respectively) was noted, whereas in the case of the CMG03 sample - it was too low $\left(6.47 \mathrm{~mm}^{2} / \mathrm{s}\right)$.

On the one hand, too high viscosity greatly hampers the oil spreading on the surfaces of the cooperating parts of the engine, while too low viscosity (too thin oil film) results in a lack of adequate protection against friction. High soot content may be the reason for the exceedance of the limit value. In the case of diesel engines, the reason might also be the dilution of oil with fuel, and in the case of (petrol) gasoline engines - excessive oxidation. Two samples (CMG01 and CMG05) were within acceptable range.

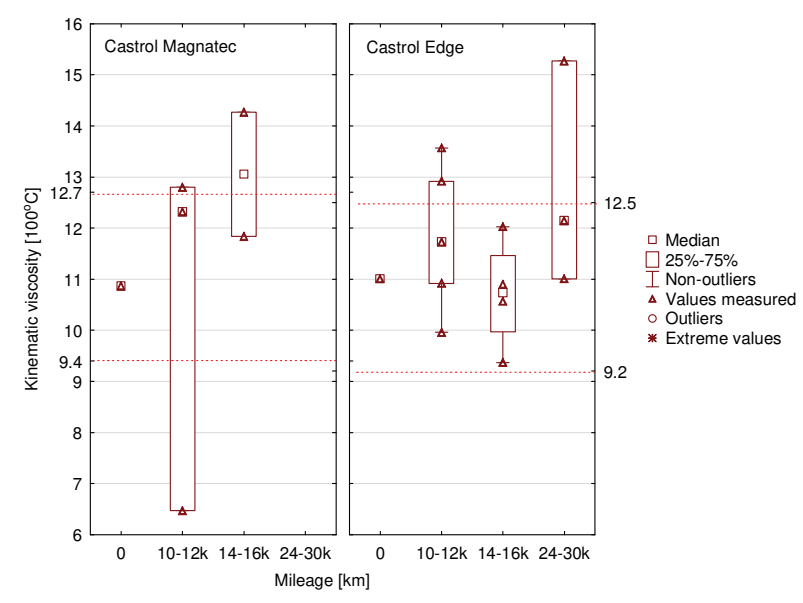

Fig. 2. Kinematic viscosity at $100^{\circ} \mathrm{C}$ of the engine oils tested
For Castrol Edge 5W30, three samples exceeded the critical value (Fig. 2). These were the following: CEG05, CED11 and CED02. In all cases, the oil viscosity became too high after the service life ended. A very high viscosity was observed for the CED11 sample after 28,000 km, indicating a rise in viscosity resulting from oil thickening by degradation products. In the remaining nine samples the kinematic viscosity was within the limits.

The next test parameters examined were total base number (TBN) and total acid number (TAN). The total base number is a measure of the alkaline reserve, thanks to which the oil has the ability to neutralize acidic oxidation or sulphate products, and the total acid number is a measure of this acidification. The results of the TBN measurements of the oil samples tested are presented in Fig. 3. Upon analyzing the TBN measurement results in used Castrol Magnatec oil samples, it was found that all of them were within the specified limits and did not fall below the accepted minimum limit of $3.7 \mathrm{mg} \mathrm{KOH} / \mathrm{g}$.

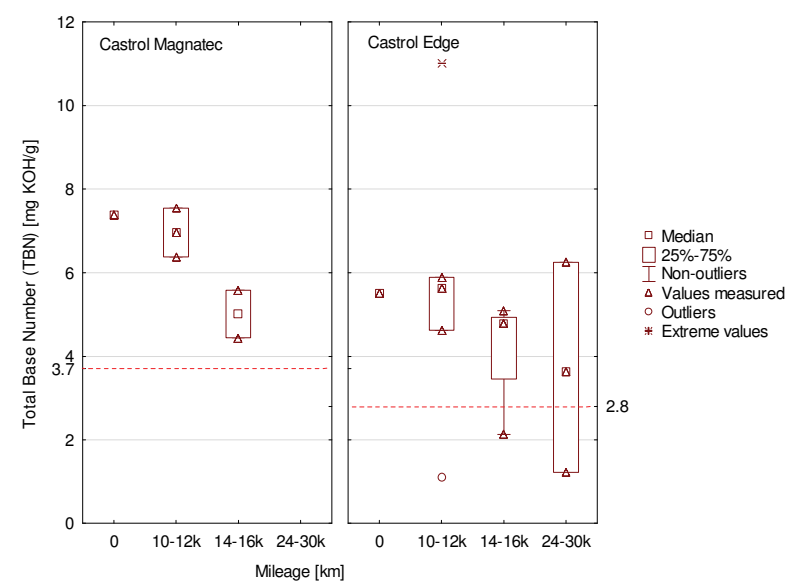

Fig. 3. The Total Base Number analysis for the engine oils tested

From among all of the analyzed samples of Castrol Edge, nine showed a value higher than the assumed minimum, while in three samples the achieved value was lower than the assumed minimum. These were the following samples: CED03 - $1.11 \mathrm{mg} \mathrm{KOH} / \mathrm{g}, \mathrm{CED} 12$ - $1.22 \mathrm{mg} \mathrm{KOH} / \mathrm{g}$ and CED06 - $2.13 \mathrm{mg} \mathrm{KOH/g}$. Such TBN values are insufficient to neutralize the acids. One sample showed a very high TBN level $-11.02 \mathrm{mg} \mathrm{KOH} / \mathrm{g}$. It was collected from a car coded as CEG05. In both examined groups, a downward trend can be observed depending on the degree of oil use.

The Total Acid Number analysis (TAN) in the Castrol Magnatec oils tested showed that three samples exceeded the assumed critical value of $3.9 \mathrm{mg} \mathrm{KOH} / \mathrm{g}$. These were: CMG04 with $6.24 \mathrm{mg} \mathrm{KOH} / \mathrm{g}$, CMG05 with $4.70 \mathrm{mg}$ $\mathrm{KOH} / \mathrm{g}$ and $\mathrm{CMG03}$ with $3.97 \mathrm{mg} \mathrm{KOH} / \mathrm{g}$ (limit value only slightly exceeded). It is noteworthy that oils up to $10-$ $12,000 \mathrm{~km}$ of mileage do not exceed the critical TAN value.

Upon analyzing the test results for Castrol Edge synthetic oil, it was observed that none of the examined samples exceeded the limit value of $4.6 \mathrm{mg} \mathrm{KOH} / \mathrm{g}$. Nevertheless, two of the samples showed values which were very close to the limit - CED12 (4.54 mg KOH/g) and CED03 (4.54 mg $\mathrm{KOH} / \mathrm{g}$ ). The results of Total Acid Number analysis for the oils tested are presented in Fig. 4. 


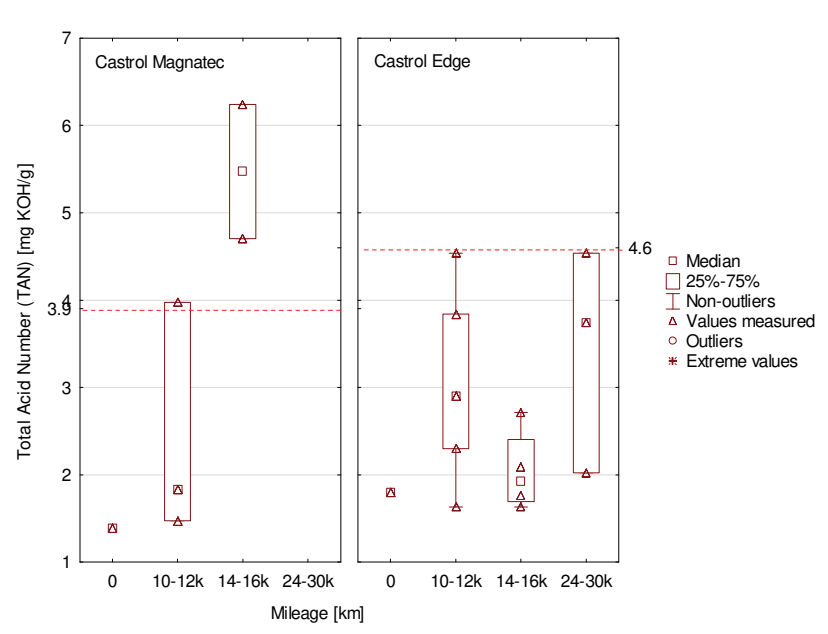

Fig. 4. The Total Acid Number analysis for the engine oils tested

Oxidation is a natural process occurring during the service-life of oil. Too high degree of oil oxidation results in oil degradation, loss of its lubricating properties and a decrease in corrosion protection. Among Castrol Magnatec $10 \mathrm{~W} / 40$ oil samples tested, only one of them exceeded the assumed critical value (CMG03 - $0.43 \mathrm{Abs} / 0.1 \mathrm{~mm})$. In the Castrol Edge 5W/30 group, two samples exceeded the limit value (CED03 - $0.46 \mathrm{Abs} / 0.1 \mathrm{~mm}$ and CED12 - 0.45 Abs $/ 0.1 \mathrm{~mm})$. The test results showed an upward trend in oxidation depending on the degree of oil use. The degree of oxidation of the engine oils tested is presented in Fig. 5.

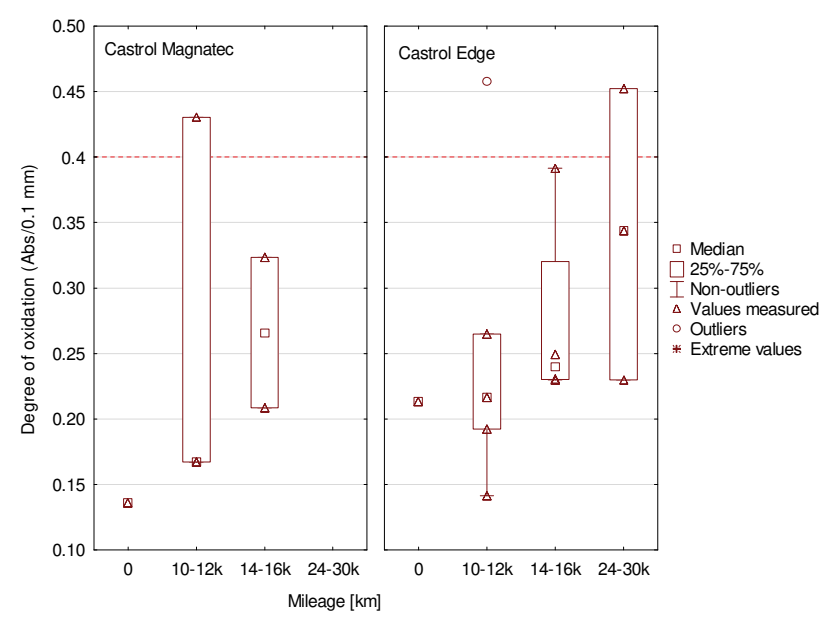

Fig. 5. The degree of oxidation of the engine oils tested

Nitration is the process by which deposits form as a result of the reaction of oil with nitrogen oxides $\left(\mathrm{NO}_{\mathrm{x}}\right)$. This process leads to the formation of oil sludge and other deposits on the metal parts of the engine, thus contributing to oil degradation, loss of its lubricating properties and a decrease in corrosion protection. Nitration is a particular problem for engines equipped with exhaust gas recirculation (EGR). The degree of nitration of the engine oils tested is shown in Fig. 6.

The highest value of the degree of nitration was observed for CMG04 - $0.203 \mathrm{Abs} / 0.1 \mathrm{~mm}$; and just like in the case of all other samples tested, the obtained value was within the limit of no more than $0.4 \mathrm{Abs} / 0.1 \mathrm{~mm}$ (the refer- ence line is outside the scale range). It is worth noting that even high levels of mileage $(30,000 \mathrm{~km})$ had no significant effect on the degree of nitration.

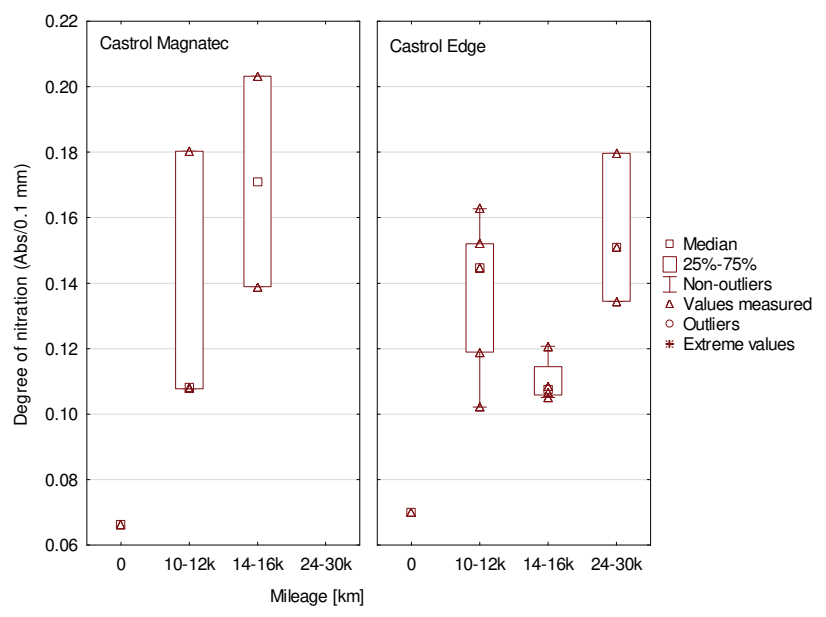

Fig. 6. The degree of nitration of the engine oils tested

The next parameter analyzed was the degree of sulfonation of used engine oils. This is a process that stems from the reaction of sulfur (mainly contained in fuel) with oxygen. As a result of this process, sediment is formed inside the engine, and with addition of water, also sulfuric acid. Sulfonation increases the wear of quality additives in engine oils. This is of particular importance if the engines are equipped with an EGR system. The degree of sulfonation of the engine oils tested are presented in Fig. 7.

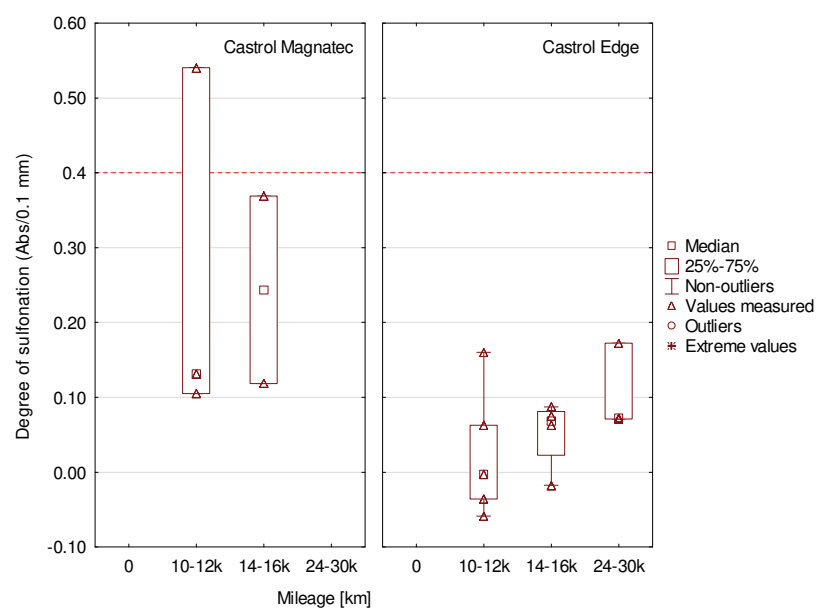

Fig. 7. The degree of sulfonation of the engine oils tested

The test results show that all of the Castrol Edge 5W30 oil samples were below the assumed maximum limit $(0.4$ Abs/0.1 mm), whereas in the group of Castrol Magnatec 10W40 oils - one sample exceeded the limit value (CMG03 $-0.54 \mathrm{Abs} / 0.1 \mathrm{~mm})$.

The last parameters tested were water (Fig. 8) and glycol content (Fig. 9). The presence of water in engine oil adversely affects the corrosion protection and leads to oil degradation. Too high water content may indicate leaks in the lubrication system, defects or leaks in water separators, or leakage from the cooling system. Upon analyzing the test 
results for the presence of water in the examined engine oils, it was found that all Castrol Magnatec oil samples showed lower values than the upper limit of tolerance, whereas in two of the Castrol Edge oil samples those values were exceeded. One of the samples was collected from a car with self-ignition engine and mileage of $10,000 \mathrm{~km}$ since the last oil change (CED02 - 0.24 Abs/0.1 mm), and the other from a car with a self-ignition engine and mileage of $28,000 \mathrm{~km}$ since the last oil change (CED11 - 0.34 Abs/0.1 mm).

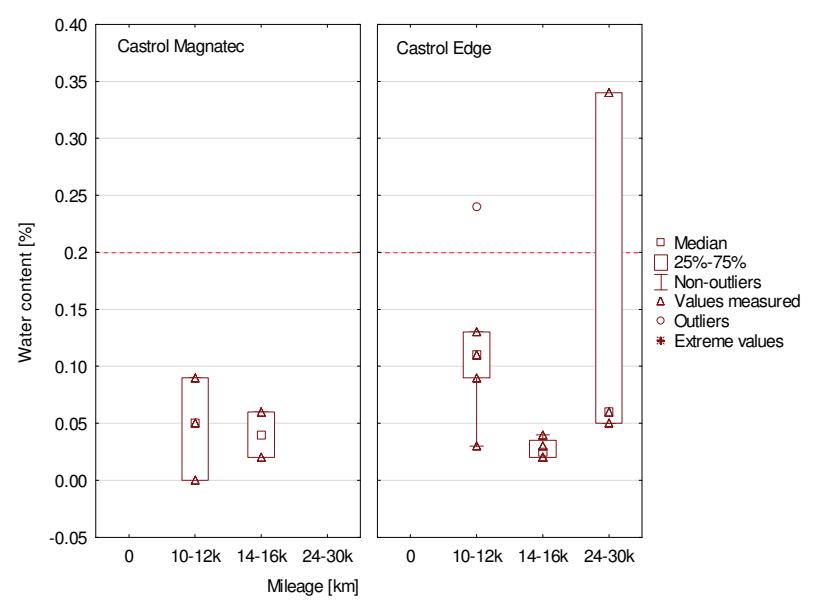

Fig. 8. The water content of the engine oils tested

Generally, there should be no glycol in engine oils. However, if glycol content is detected, it may indicate an engine defect, particularly a damaged engine head or the wear of a gasket under the engine head. Analysis of glycol content in oil can provide valuable information in situations requiring engine repair. The test results show that three of the Castrol Magnatec oil samples exceeded the assumed limit value. Two of the samples were collected from cars with spark ignition engines, one of them had the mileage of $10,000 \mathrm{~km}$ since the last oil change (CMD01 - 1.6\%), and the other - the mileage of $13,000 \mathrm{~km}$ since the last oil change (CMG04-1.3\%). The third sample was collected from a car with spark ignition engine and LPG gas installation with the mileage of $15,000 \mathrm{~km}$ since the last oil change (CMG05-1.5\%).

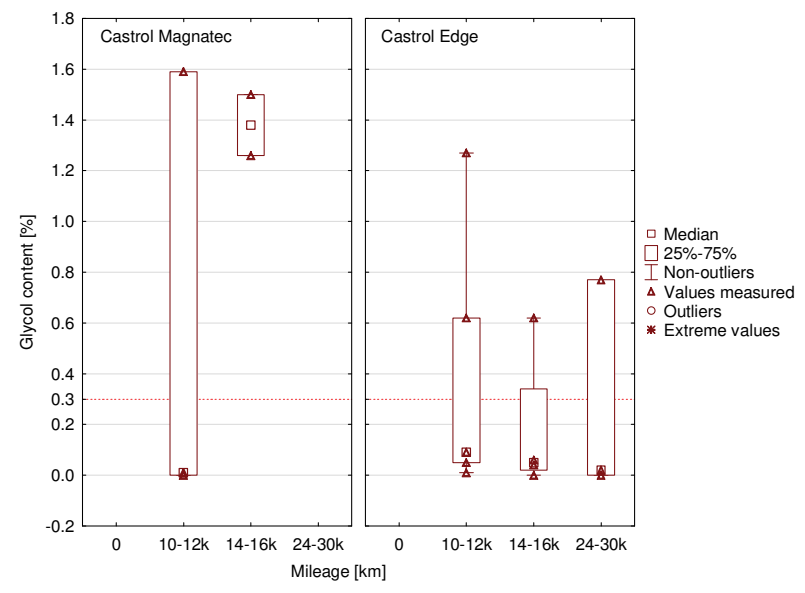

Fig. 9. The glycol content of the engine oils tested
In the Castrol Edge group of oils, it was found that as many as four samples exceeded the assumed limit value. Three of the samples were collected from cars with selfignition engines and the following mileages since the last oil change: 12,000 (CED04), 15,000 (CED07) and 28,000 $\mathrm{km}$ (CED11). One sample, collected from a spark ignition engine with the mileage of $12,000 \mathrm{~km}$ (CEG05) showed the highest level of glycol content $-1.27 \%$ which may indicate that some of engine components should be repaired.

Exceedances of the limit values for the analyzed oil parameters are summarized in Table 4 . In the group of vehicles whose engines were lubricated with a semi-synthetic oil, two and more exceedances were found for each of the tested vehicles. The situation was different for vehicles whose engines were lubricated with a synthetic oil. In three of the cars tested no exceedances were found, and in two other cars only one exceedance per car. The parameter that showed the highest number of exceedances was the kinematic viscosity at $40^{\circ} \mathrm{C}$ - for synthetic oil seven exceedances were observed (out of 12 samples tested), and five (out of 5 samples tested) for semi-synthetic oil. The parameters that showed the lowest number of exceedances for synthetic oils were: the degree of oxidation, water content and TAN for which two exceedances each were recorded. It is worth noting that no exceedances were found for the degree of nitration and sulfonation. Similar situation was observed for semi-synthetic oils where the lowest number of exceedances was found for the degree of oxidation and sulfonation one oil sample per each parameter. No exceedances were found for the degree of nitration, water content and TBN.

Upon analyzing the results of the study, it can be observed that it might be difficult to detect a relationship between the oil quality at the point of oil change with the technical state of the engine expressed by its mileage, as the exceedances were found for both vehicles with the mileage of about $100,000 \mathrm{~km}$ and for vehicles with the mileage of over $200,000 \mathrm{~km}$. At the same time, in the group of synthetic oils for vehicles with no exceedances found, there were some with the mileage of $120-130,000 \mathrm{~km}$ as well as some with the mileage of nearly $300,000 \mathrm{~km}$.

When taking into account the mileage since the last oil change, there are no clear trends visible either. The semisynthetic oil was generally changed after 10-15,000 km, whereas the synthetic one from $10,000 \mathrm{~km}$ up to even $30,000 \mathrm{~km}$ (according to the engine manufacturer's approval as long-life oil). In several cases, engine oil with the mileage of 16,000 and even $24,000 \mathrm{~km}$ since the last change did not show any limit value exceedances. On the other hand, in some cases even relatively small mileage (of ca. 10-13,000 km) would exhibit exceedances for more than one parameter. It may then be concluded that oil condition strongly depends on the operating conditions. In only two cases (CED04 and CMG04) the decision to change oil after only $11,000-13,000 \mathrm{~km}$ traveled was actually made too late. On the other hand, one of the vehicles (CED10), after $24,000 \mathrm{~km}$ traveled, showed no exceedances. The abovementioned vehicles were off-road ones, so it might be presumed that the first two were actually used in difficult road conditions (the oil wears faster), and the third one was operated in more standard road driving conditions. These 
cases suggest that the oil change interval should be determined not only on the basis of the car mileage (mileage since the last oil change), but also taking into account the conditions under which the vehicle is generally used. According to Idzior and Wichtowskiej [2016], with regard to the purchase price of a new or used engine, frequent oil changes are a relatively low cost procedure. It should be considered, however, that oil changes should not take place more often than every $10,000 \mathrm{~km}$ - and that is mostly due to environmental reasons - unless the conditions of use do not allow for such long use of oil. Individual parameter values should always be analyzed together with the limit value exceedances.

Table 4. Exceedances of the limit values for the analyzed oil parameters: a summary

\begin{tabular}{|c|c|c|c|c|c|c|c|c|c|c|c|c|c|c|c|}
\hline & & $\begin{array}{l}\text { Sample code/ Make } \\
\text { of car }\end{array}$ & Engine & $\begin{array}{c}\text { Car } \\
\text { mileage } \\
{[\mathrm{km}]}\end{array}$ & $\begin{array}{c}\text { Mileage } \\
\text { since last } \\
\text { oil change } \\
{[\mathrm{km}]}\end{array}$ & $\begin{array}{c}\text { Viscosity } \\
\text { at } \\
40^{\circ} \mathrm{C}\end{array}$ & $\begin{array}{c}\text { Viscosity } \\
\text { at } \\
100^{\circ} \mathrm{C}\end{array}$ & TAN & TBN & $\begin{array}{l}\text { Degree of } \\
\text { oxidation }\end{array}$ & $\begin{array}{l}\text { Degree } \\
\text { of } \\
\text { nitration }\end{array}$ & $\begin{array}{c}\text { Degree } \\
\text { of sulfo- } \\
\text { nation }\end{array}$ & $\begin{array}{l}\text { Water } \\
\text { content }\end{array}$ & $\begin{array}{l}\text { Glycol } \\
\text { content }\end{array}$ & Total \\
\hline \multirow{14}{*}{ 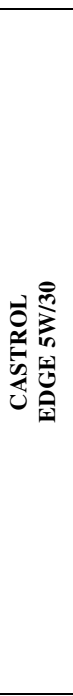 } & 1. & $\begin{array}{l}\text { CED01/Volvo XC } \\
60\end{array}$ & diesel & 52000 & 10000 & $\checkmark$ & $\mathrm{X}$ & $\checkmark$ & $\checkmark$ & $\checkmark$ & $\checkmark$ & $\checkmark$ & $\checkmark$ & $\checkmark$ & $1 / 9$ \\
\hline & 2. & CED02/Volvo V50 & diesel & 192000 & 10000 & $\mathrm{X}$ & $\checkmark$ & $\checkmark$ & $\checkmark$ & $\checkmark$ & $\checkmark$ & $\checkmark$ & $\mathrm{X}$ & $\checkmark$ & $2 / 9$ \\
\hline & 3. & $\begin{array}{l}\text { CED03/Nissan X } \\
\text { trail }\end{array}$ & diesel & 243000 & 11000 & $\mathrm{X}$ & $\checkmark$ & $\mathrm{X}$ & $\mathrm{X}$ & $\mathrm{X}$ & $\checkmark$ & $\checkmark$ & $\checkmark$ & $\checkmark$ & $4 / 9$ \\
\hline & 4. & CED04/Opel Astra & diesel & 205000 & 12000 & $\mathrm{X}$ & $\mathrm{X}$ & $\checkmark$ & $\checkmark$ & $\checkmark$ & $\checkmark$ & $\checkmark$ & $\checkmark$ & $\mathrm{X}$ & $3 / 9$ \\
\hline & 5. & CEG05/Audi A6 & gasoline & 240000 & 12000 & $\mathrm{X}$ & $\checkmark$ & $\checkmark$ & $\checkmark$ & $\checkmark$ & $\checkmark$ & $\checkmark$ & $\checkmark$ & $\mathrm{X}$ & $2 / 9$ \\
\hline & 6. & CED06/Seat Leon & diesel & 122000 & 14000 & $\checkmark$ & $\checkmark$ & $\checkmark$ & $\mathrm{X}$ & $\checkmark$ & $\checkmark$ & $\checkmark$ & $\checkmark$ & $\checkmark$ & $1 / 9$ \\
\hline & 7. & CED07/Audi Q7 & diesel & 166000 & 15000 & $\mathrm{X}$ & $\checkmark$ & $\checkmark$ & $\checkmark$ & $\checkmark$ & $\checkmark$ & $\checkmark$ & $\checkmark$ & $\mathrm{X}$ & $2 / 9$ \\
\hline & 8. & \begin{tabular}{|l} 
CED08/Skoda \\
Fabia \\
\end{tabular} & diesel & 136000 & 15000 & $\checkmark$ & $\checkmark$ & $\checkmark$ & $\checkmark$ & $\checkmark$ & $\checkmark$ & $\checkmark$ & $\checkmark$ & $\checkmark$ & $0 / 9$ \\
\hline & 9. & \begin{tabular}{|l|} 
CED09/Skoda \\
Fabia \\
\end{tabular} & diesel & 120000 & 16000 & $\checkmark$ & $\checkmark$ & $\checkmark$ & $\checkmark$ & $\checkmark$ & $\checkmark$ & $\checkmark$ & $\checkmark$ & $\checkmark$ & $0 / 9$ \\
\hline & $\begin{array}{l}1 \\
0 . \\
\end{array}$ & \begin{tabular}{|l|} 
CED10/VW \\
Touareg \\
\end{tabular} & diesel & 293000 & 24000 & $\checkmark$ & $\checkmark$ & $\checkmark$ & $\checkmark$ & $\checkmark$ & $\checkmark$ & $\checkmark$ & $\checkmark$ & $\checkmark$ & $0 / 9$ \\
\hline & $\begin{array}{l}1 \\
1 . \\
\end{array}$ & CED11/BMW X5 & diesel & 212000 & 28000 & $\mathrm{X}$ & $\mathrm{X}$ & $\checkmark$ & $\checkmark$ & $\checkmark$ & $\checkmark$ & $\checkmark$ & $\mathrm{X}$ & $\mathrm{X}$ & $4 / 9$ \\
\hline & $\begin{array}{l}1 \\
2 .\end{array}$ & CED12/BMW E61 & diesel & 169000 & 30000 & $\mathrm{X}$ & $\checkmark$ & $\mathrm{X}$ & $\mathrm{X}$ & $\mathrm{X}$ & $\checkmark$ & $\checkmark$ & $\checkmark$ & $\checkmark$ & $4 / 9$ \\
\hline & \multicolumn{5}{|c|}{ Total } & 7 & 3 & 2 & 3 & 2 & $\mathbf{0}$ & $\mathbf{0}$ & 2 & 4 & \\
\hline & & $\begin{array}{l}\text { Sample code/ } \\
\text { Make of car }\end{array}$ & Engine & $\begin{array}{c}\text { Car } \\
\text { mileage }\end{array}$ & $\begin{array}{c}\text { Mileage } \\
\text { since last } \\
\text { oil change }\end{array}$ & $\begin{array}{c}\text { Viscosity } \\
\text { at } \\
40^{\circ} \mathrm{C}\end{array}$ & $\begin{array}{c}\text { Viscosity } \\
\text { at } \\
100^{\circ} \mathrm{C}\end{array}$ & TAN & TBN & $\begin{array}{l}\text { Degree of } \\
\text { oxidation }\end{array}$ & \begin{tabular}{|c|}
$\begin{array}{c}\text { Degree } \\
\text { of } \\
\text { nitration }\end{array}$ \\
\end{tabular} & $\begin{array}{r}\text { Degree of } \\
\text { sulfonation }\end{array}$ & $\begin{array}{l}\text { Water } \\
\text { content }\end{array}$ & $\begin{array}{l}\text { Glycol } \\
\text { content }\end{array}$ & Total \\
\hline \multirow{6}{*}{ 紊 } & 1. & \begin{tabular}{|l|} 
CMD01/Ford \\
Mondeo MK II \\
\end{tabular} & diesel & 294000 & 10000 & $\mathrm{X}$ & $\checkmark$ & $\checkmark$ & $\checkmark$ & $\checkmark$ & $\checkmark$ & $\checkmark$ & $\checkmark$ & $\mathrm{X}$ & $2 / 9$ \\
\hline & 2. & $\begin{array}{l}\text { CMD02/Mercedes } \\
\text { C220 }\end{array}$ & diesel & 195000 & 10000 & $\mathrm{X}$ & $\mathrm{X}$ & $\checkmark$ & $\checkmark$ & $\checkmark$ & $\checkmark$ & $\checkmark$ & $\checkmark$ & $\checkmark$ & $2 / 9$ \\
\hline & 3. & $\begin{array}{l}\text { CMG03/Ford } \\
\text { Mondeo MK II }\end{array}$ & gasoline & 233000 & 12000 & $\mathrm{X}$ & $\mathrm{X}$ & $\mathrm{X}$ & $\checkmark$ & $\mathrm{X}$ & $\checkmark$ & $\mathrm{X}$ & $\checkmark$ & $\checkmark$ & $5 / 9$ \\
\hline & 4. & \begin{tabular}{|l|} 
CMG04/Daihatsu \\
Terios \\
\end{tabular} & gasoline & 181000 & 13000 & $\mathrm{X}$ & $\mathrm{X}$ & $\mathrm{X}$ & $\checkmark$ & $\checkmark$ & $\checkmark$ & $\checkmark$ & $\checkmark$ & $\mathrm{X}$ & $4 / 9$ \\
\hline & 5. & \begin{tabular}{|l|} 
CMG05/Skoda \\
Romster
\end{tabular} & $\begin{array}{l}\text { gasoline } \\
+ \text { LPG }\end{array}$ & 280000 & 15000 & $\mathrm{X}$ & $\checkmark$ & $\mathrm{X}$ & $\checkmark$ & $\checkmark$ & $\checkmark$ & $\checkmark$ & $\checkmark$ & $\mathrm{X}$ & $3 / 9$ \\
\hline & \multicolumn{5}{|c|}{ Total } & 5 & 3 & 3 & 0 & 1 & 0 & 1 & 0 & 3 & \\
\hline
\end{tabular}

\section{Conclusions}

The parameters of in-service engine oils oftentimes vary depending on the operating conditions, number of kilometers traveled (mileage), operating time, technical conditions of the engine and its components. Any changes in the engine oil properties exceeding the lower and upper limit ranges adopted for them bring negative effects in the form of the possibility of damaging the engine or its components [3]. The assessment of the condition of used lubricating oils is based on the in-depth oil analysis. The oil condition is compared with the parameters of a fresh oil and then with the limit values which the oil should not reach. If at least one parameter value reaches the limit, it means that the oil does not function properly in the engine. In order to restore normal operating conditions, it is necessary to take remedial action, most often in the form of oil change. The conducted research made it possible to determine the distribution of the exceedances for the measured parameters of the engine oils tested. The following exceedances have been found: kinematic viscosity at $40^{\circ} \mathrm{C}(70 \%)$ and at $100^{\circ} \mathrm{C}(35 \%)$, the glycol content (41\%) and the Total Acid Number (29\%).
The obtained results did not bring an unequivocal answer to the question posed, whether the mileage since the last oil change - generally used to determine the oil change interval - is actually the most reliable criterion. In the case of three vehicles CED08/Skoda Fabia, CED09/Skoda Fabia and CED10/VW Touareg) no exceedances were found, so the oil still retained its useful life although the vehicle user decided to change it. In two other cases one exceedance per vehicle was found, which might suggest that the oil change interval assumed was appropriate. Yet, in over $70 \%$ of the samples tested more than one exceedance was detected. Assuming then that the best moment to change oil is when only one of its parameters exceeds the limit value, more than two-thirds of oils tested were actually changed after exceeding the critical point. However, considering the number of these exceedances and the parameters in which the exceedances have taken place, the assessment becomes even more convoluted. Small deviations can only become the basis for further oil monitoring.

Based on the obtained results it may be concluded that considering the vehicle mileage and the mileage since the last oil change, it is impossible to determine the speed of oil 
degradation. Some vehicles may often be used on highways, and others will be primarily used for urban or even off-road driving. Depending on the operating conditions, the process of oil degradation may be different; and thus, changing those conditions during the car use will be reflected by different speeds of oil degradation. Therefore, the point at which the oil should be changed will also vary. That is why, different time intervals should be used to replace the engine oil depending on the vehicle's operating profile. Such an approach may bring many benefits, the most important of which is the reduction of vehicle maintenance costs.

\section{Bibliography}

[1] BASU, A., BERNDORFER, A., BUELNA, C. et al. Smart sensing of oil degradation and oil level measurements in gasoline engines. SAE Technical Paper. 2000.

[2] GOMÓŁKA, L., AUGUSTYNOWICZ, A., MACIĄG, A. Analiza stopnia degradacji oleju smarującego w silnikach spalinowych. Silniki Spalinowe. 2011, 50.

[3] IDZIOR, M., WICHTOWSKA, K. Badanie wpływu przebiegu pojazdów na zmiany właściwości olejów silnikowych. Autobusy: technika, eksploatacja, systemy transportowe. 2016, 17(6).

[4] JUN, H.-B., KIRITSIS, D., GAMBERA, M. et al. Predictive algorithm to determine the suitable time to change automotive engine oil. Computers \& Industrial Engineering. 2006, 51(4).

[5] KRAL, J., KONECNY, B., KRAL, J. et al. Degradation and chemical change of longlife oils following intensive use in automobile engines. Measurement. 2014, $\mathbf{5 0 .}$

[6] KRUPOWIES, J. Analiza zmian właściwości użytkowych olejów smarowych firmy BP w czasie ich eksploatacji. Zeszyty Naukowe Akademia Morska w Szczecinie. 2006, 10 (82).

[7] KRUPOWIES, J. Badania i ocena zmian właściwości użytkowych olejów urządzeń okrętowych. Studia Akademia Morska w Szczecinie. 2009, 49.
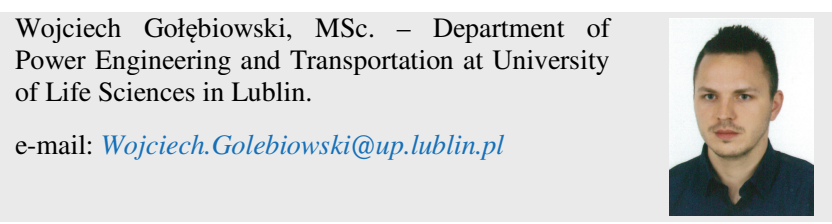

Grzegorz Zając, DSc., DEng. - Department of Power Engineering and Transportation at University of Life Sciences in Lublin.

e-mail: Grzegorz.Zajac@up.lublin.pl
The research should be regarded as a pilot study, aimed at addressing the basic aspects of the problem. It should be noted, however, that introducing more vehicles and parameters into the study, as well as investigating various driving styles, might make it possible to verify the appropriateness of the oil change standards proposed by manufacturers.

\section{Acknowledgements}

The publication was funded by appropriations of the Faculty of Production Engineering University of Life Sciences in Lublin and Faculty of Commodity Science, Cracow University of Economics, within the framework of grants to maintain the research potential.

[8] MALINOWSKA, M. Analiza zanieczyszczeń oleju silnikowego stosowanego w silniku Cegielski-Sulzer 3AL25/30. Zeszyty Naukowe Akademii Morskiej w Gdyni. 2014, 83.

[9] SEJKOROVÁ, M., HURTOVÁ, I., GLOS, J. et al. Definition of a Motor Oil Change Interval for High-Volume Diesel Engines Based on its Current Characteristics Assessment. Acta Universitatis Agriculturae et Silviculturae Mendelianae Brunensis. 2017, 65(2).

[10] URZĘDOWSKA, W., STĘPIEŃ, Z. Wybrane zagadnienia dotyczące zmian właściwości silnikowego oleju smarowego w eksploatacji. Nafta-Gaz. 2012, 12.

[11] VASANTHAN, B., DEVARADJANE, G., SHANMUGAM, V. Online condition monitoring of lubricating oil on test bench diesel engine \& vehicle. Journal of Chemical and Pharmaceutical Sciences. 2015, 9.

[12] WOLAK, A., ZAJAC, G. The kinetics of changes in kinematic viscosity of engine oils under similar operating conditions. Eksploatacja i Niezawodnosc - Maintenance and Reliability. 2017, 19(2).

[13] WOLAK, A., ZAJAC, G. Changes in the operating characteristics of engine oils: a comparison of the results obtained with the use of two automatic devices. Measurement. 2017, $113 \mathrm{C}$.

Artur Wolak, DEng. - Department of Industrial Commodity Science at Cracow University of Economics.

e-mail: Artur.Wolak@uek.krakow.pl

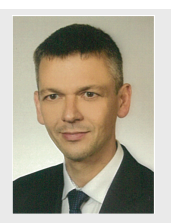

